\title{
角形鋼管柱の左右にせいの異なる梁が接合される場合の 梁の剛性と耐力に関する研究 \\ STIFFNES AND MOMENT CAPACITY OF H-SHAPED BEAM CONNECTED TO RHS-COLUMN WITHOUT DIAPHRAGM AT ITS LOWER FLANGE LEVEL
}

\author{
立山英二*, 井上一朗**, 松 村弘 道*** \\ Eiji TATEYAMA, Kazuo INOUE and Hiromichi MATSUMURA
}

\begin{abstract}
At the connection of H-shaped beams and RHS-column as shown in Fig. 2, stiffness and moment capacity of smaller depth beam are govered by rigidity of column flange. In this paper, analytical study for predicting elastic stiffness and moment capacity of beam mentioned above and experimental results are reported.

The elastic stiffness of beam was derived by assumig the column flange would behave as grid beams.

For the moment capacity, the theoretical expression was developed based on the yield line theory.

And to confirm the precision, the analytical results were compared with the experimental results obtained from 14 simple beam type specimens under monotonic loading and 5 cruciform type specimens of beam-to-column sub-assemblage under cyclic loading. In those tests, the parameters of specimens were thickness of RHS-column, disparity between lower beam flange and diaphragm, and width of beam-flange.

The analytical results were closely coinside with the corresponding test results.
\end{abstract}

Keywords : beam connected to RHS-column, moment capacity, yield line theory

\section{1. 序}

1981 年にいわゆる「新耐震設計法」が施行されて以来, 低層加ら高層に至る鉄骨造骨組の柱にはその断面特性の 利点を生かして角形鋼管柱が多用されている。

ラーメン架構中の角形鋼管柱・梁接合部では，梁フラ ンジから加わる応力集中による仕口の局部変形に対処 し，十分な強度と剛性を有するための接合部の補剛形式 としていくつかの代表的な工法があるが，「鋼管構造設 計施工指針・同解説」”に与えられている許容力式や設 計・施工上の注意事項は外ダイヤフラム形式の柱・梁接 合部に関するものが主である。しかし，実施設計では外 ダイヤフラム形式の補剛が採用されることはまれで，中 低層の鉄骨造骨組ではほとんど通しダイヤフラム形式の 補剛が慣用されている。

最近, 通しダイヤフラム形式補剛の接合部で左右の梁 に段差が無い標準的な接合部（図一1 以下，標準接合部
と略記）については, 実験的, 解析的研究成果 ${ }^{2)-5)}$ が発 表されている。しかし，現実の鉄骨造骨組は，このよう な標準的な接合部だけで構成されているわけではなく， 特殊な接合部も存在する。そのような特殊接合部の一つ

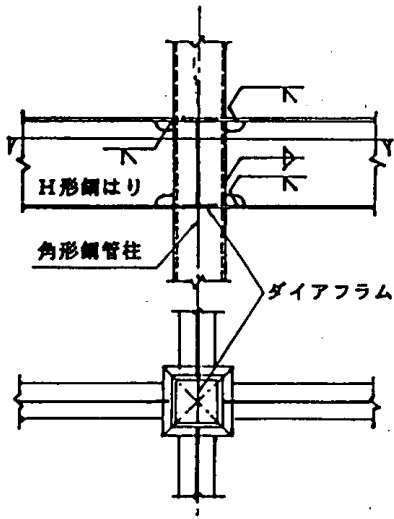

図一1，通しダイアフラム形式の標準接合部

本論文の一部は文献 11）において発表済みである。

* 近畿大学 講師・工修

** 大阪大学 助教授 $\cdot$ 工博

***（株）日本鋼管 主任研究員・工修

Lecturer of Kinki Univ., M. Eng.

Associate Prof. of Osaka Univ., Dr. Eng.

Research Engineer of Nihon Kokan Co., M. Eng. 


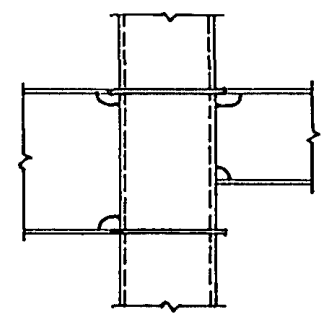

図一2 段違い梁接合部

に機能上の要求，または鉄骨重量の軽娍目的等により角 形鋼管柱の左右で梁断面を変化させ，梁に段差を設けた 接合部（図一2 以下，段違い梁接合部と呼ぶ）がある。 このような接合部の補強方法としては，段違い梁の下フ ランジ位置に内ダイヤフラム，または，外ダイヤフラム を導入するか，もしくは，ハンチを付ける等の方法があ る。どの補強方法を採るかは設計条件に応じて選択され るものと考えられるが，上り合理的，効果的な補強を行 うためには無補強の場合の応力伝達機構, 剛性, 耐力等 について把握しておく必要がある。無補強段違い梁接合 部では, 梁の下フランジが不連続となり，柱・梁接合部 まわりの弾塑性挙動は標準接合部の場合と異なる。段違 い梁接合部の弾塑性挙動・設計法に関する研究は極めて 少なく, わずかに中尾 ${ }^{6), 71}$, 平野 ${ }^{81,91}$, 福知 ${ }^{10)} ら の \mathrm{H}$ 断面 柱・梁接合部に関する研究が見られるにすぎず，角形鋼 管柱と段違い梁の接合部に関する資料は皆無である。

本研究は，角形鋼管柱・段違い梁接合部の力学的特性 の基礎的検討を目的として, 降伏線理論により無補強段 違い梁接合部の梁耐力の算定式を導き，段違い梁接合部 を有する骨組の分解架構についての単調，および絽返し 載荷試験結果に適用し，その妥当性について検討する。

\section{2. 実験方法}

実験は梁の段差 $(e)$, 角形鋼管柱の管厚 $\left(t_{r}\right)$ ，および, 梁幅を実験パラメータとして,以下の系列別実験を行う。

I）完全に剛なパネルゾーンに接合する単純梁の単調載 荷実験

II）角形鋼管柱・梁標準接合部の単純梁形試験体による 単調載荷実験

四）角形鋼管柱・無補強段違い梁接合部の単純梁形試験 体による単調載荷実験

IV) 角形鋼管柱・無補強段違い梁接合部の十字型架構に よる繰返し加力実験

\section{1 試験体の形状・法之材料の機械的性質}

試験体は上記に示すように，単純梁形と十字形の 2 種 類であり,試験体の梁はすべて溶接組立 H 形断面である。 角形鋼管柱は冷間プレス成型による管厚 $16 \mathrm{~mm}$ のも のを除いてすべて冷間ロール成型鋼管であり，その製造 過程において円形から角形に成型されたものである。

単純梁試験体は，図一-3(a)〜 (c) および表一1に示す

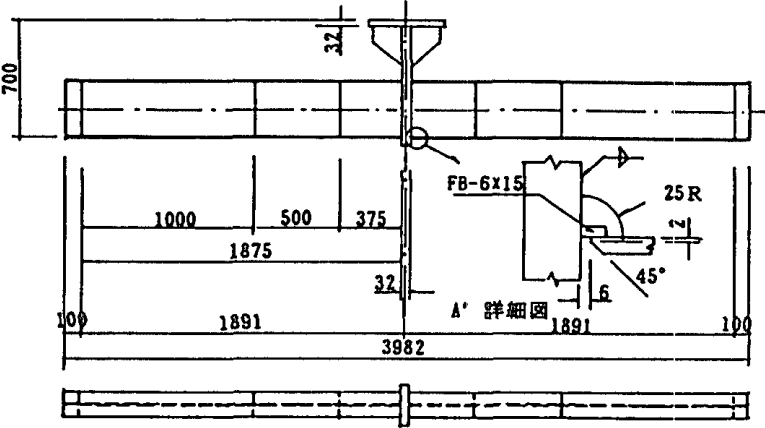

（a）BOシリース試堅恢

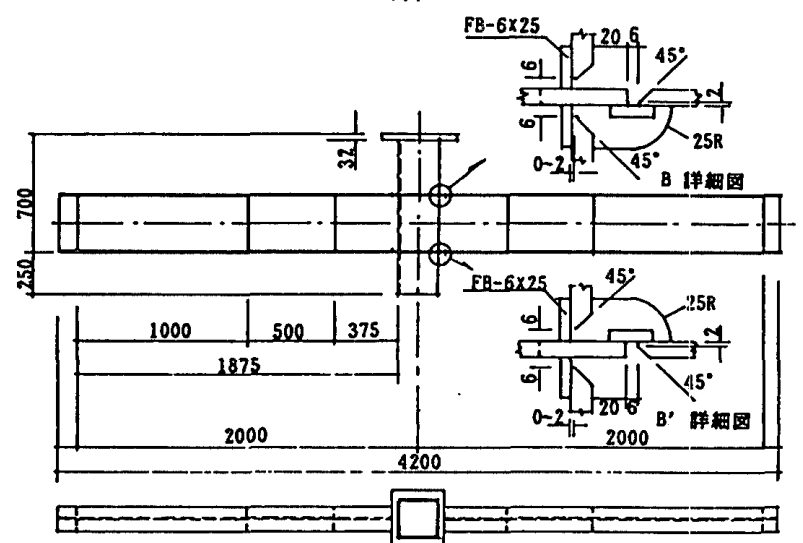

(b) B1シリーズ試験佮

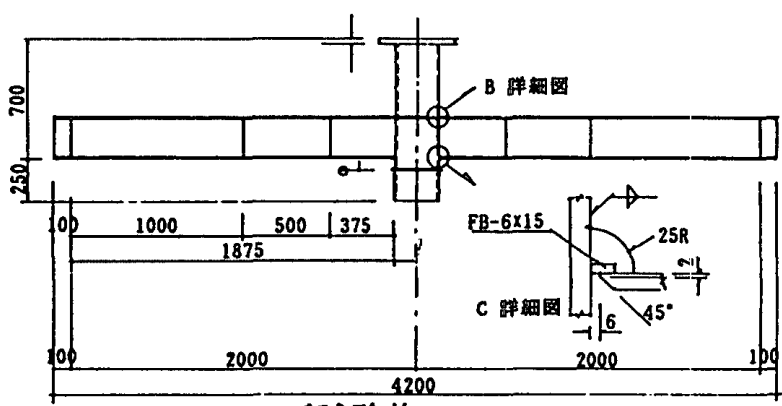

(c) B2シリーズ斌駼体

図一－3 単純梁形試験体

表一1 単純梁形試験体

\begin{tabular}{|c|c|c|c|}
\hline Specimen & Beam & Column & e $(\mathrm{mm})$ \\
\hline B0-1 & $\mathrm{BH}-350 \times 150 \times 6 \times 9$ & PL-32 & \\
\hline B $0-2$ & $\mathrm{BH}-250 \times 125 \times 6 \times 9$ & & - \\
\hline $\mathrm{B} 0-3$ & $\mathrm{BH}-250 \times 175 \times 6 \times 9$ & " & $=$ \\
\hline B1-1 & $\mathrm{BH}-350 \times 150 \times 6 \times 9$ & $0-250^{2} \times 6$ & 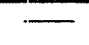 \\
\hline B1-2 & . & $0-250^{2} \times 12$ & $\ldots$ \\
\hline$B 1-3$ & " & $0-250^{2} \times 16$ & - \\
\hline B2-1 & $-250 \times 125$ & $0-250^{2} \times 6$ & 50 \\
\hline B2 & " & $0-250^{2} \times 12$ & 25 \\
\hline B2-3 & " & 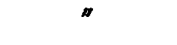 & 50 \\
\hline B 2-4 & " & " & 100 \\
\hline B2-5 & " & $0-250^{2} \times 16$ & 100 \\
\hline B2-6 & $\mathrm{BH}-250 \times 175 \times 6 \times 9$ & $0-250^{2} \times 12$ & 25 \\
\hline B2- & " & , & 50 \\
\hline B2-8 & " & " & 100 \\
\hline
\end{tabular}

B0，B1，B2 の各シリーズから成っている。B0 シリー ズの試験体は，図一 $3(\mathrm{a})$ に示すように中央の $32 \mathrm{~mm}$ の 鋼板の両側に $\mathrm{H}$ 形鋼を溶接したものであり，接合部が剛 


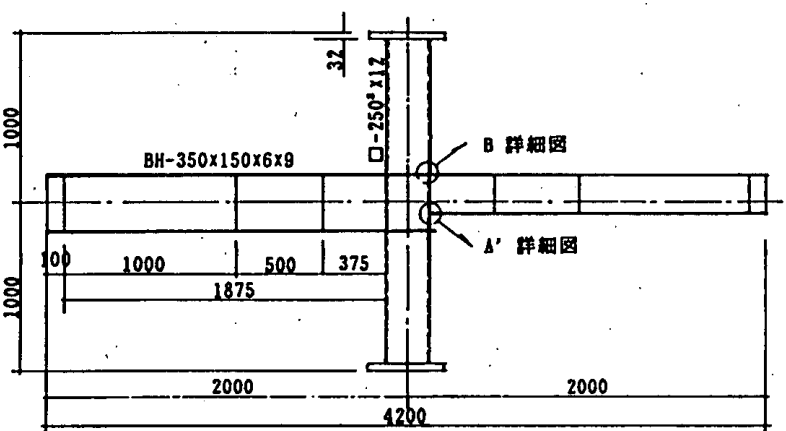

図一4 十字形試験体
表一3 材料の機械的性質

\begin{tabular}{|c|c|c|c|c|c|}
\hline \multicolumn{2}{|c|}{ Specimen } & \multirow{3}{*}{$\begin{array}{c}\text { Grade } \\
\text { SS41 } \\
\text { }\end{array}$} & \multirow{2}{*}{$\begin{array}{c}\begin{array}{c}\sigma \mathrm{Y} \\
\left(\mathrm{t} / \mathrm{con}^{2}\right)\end{array} \\
3.04\end{array}$} & \multirow{2}{*}{$\begin{array}{c}\begin{array}{c}\sigma \text { в }^{2} \\
\left(\mathrm{t} / \mathrm{ctif}^{2}\right)\end{array} \\
4.67\end{array}$} & \multirow{2}{*}{$\begin{array}{l}\text { EL. } \\
\frac{(\%)}{30}\end{array}$} \\
\hline Plate & $P L-6$ & & & & \\
\hline & $P L-9$ & & 3.10 & 4.41 & 32 \\
\hline \multirow[t]{3}{*}{ RHS } & $\square-250^{2} \times 6$ & STKR41 & $3.62^{\star}$ & 4.49 & 28 \\
\hline & {$\left[-250^{2} \times 12\right.$} & " & $3.83 \star$ & 4.55 & 29 \\
\hline & $\square-250^{2} \times 16$ & 。 & $3.48 \star$ & 4.85 & 23 \\
\hline
\end{tabular}

註）試験片はJIS Z 2201に準拋し、Plateについては 1号武験片、RHSについては5号試験片である。

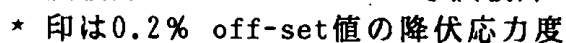

表一2 十字形試験体

\begin{tabular}{|c|c|c|c|c|}
\hline \multirow{2}{*}{ Specimen } & \multicolumn{2}{|c|}{ Beam } & \multirow{2}{*}{ Column } & \multirow{2}{*}{ Column Axial Force } \\
\hline & Left Side & Right Side & & \\
\hline $\mathrm{CB}-1$ & $\mathrm{BH}-350 \times 150 \times 6 \times 9$ & $\mathrm{BH}-350 \times 150 \times 6 \times 9$ & $0-250^{2} \times 12$ & 0 \\
\hline $\mathrm{CB}-2$ & $\pi$ & " & , & $133\left(\mathrm{~N} / \mathrm{N}_{\mathrm{P}}=0.33\right)$ \\
\hline $\mathrm{CB}-3$ & D & $\mathrm{BH}-250 \times 125 \times 6 \times 9$ & " & " \\
\hline $\mathrm{CB}-4$ & $n$ & $"$ & 。 & $n$ \\
\hline $\mathrm{CB}-5$ & $n$ & $\mathrm{BH}-250 \times 175 \times 6 \times 9$ & " & ". \\
\hline
\end{tabular}

$\mathrm{Np}$ : 柱の降伏軸力

な場合の梁の曲げ剛性や曲げ耐力に関する基準値を把握 するためのものである。B1 シリーズの試験体は, 梁ウェ ブのモーメント伝達性状を検討するためのものであり， 表一1に示すように，角形鋼管柱の管厚を実験パラメー タとしている。B2 シリーズの試験体は, 無補強段違い 梁のモーメント伝達性状を検討するためのもので，角形 鋼管柱の管厚, 梁の下フランジとダイアフラムとの食い 違い量 (断差: $e$ ), 梁のフランジ幅をパラメータとし, 総数 8 体である。十字形試験体 (CB シリーズ) は, 以 上の単純梁形式の実験で得られた結果・結論を, 地震時 に近い忘力状態を再現して確認するための試験体であ る。試験体は 4 種類で総数 5 体あり, 図一 4 , 表一 2 に その形状・寸法などを示す。この試験体の柱やパネル ゾーンは弾性域にとどまるように断面を選定している。 図一 3,4 に示すように，単純梁形および十字形のすべて の試験体に対して, 柱面から加力点までの H形鋼梁の長 さは等しく, $1875 \mathrm{~mm}$ である。

使用材料の機械的性質を表一 3 に，各試験体の梁およ び柱の断面諸量を表一4に示す。

\section{2 加力方法}

加力装置は，単純梁形試験体と十字形試験体に対して
共通であり，加力装置に単純梁形試験体をセットした状 況を図一5(a)に，また，十字形試験体をセットした状 洗を図一5(b) に示す。ただし，十字形試験体は装置の 都合上，上下が逆にセットされている。試験体の梁は， 横座屈を防ぐため, 内側の 2 箇所の縦スチフナーの位置 (図一3，4）で横方向の移動が拘束されている。単純梁 形試験体の中央部は加力装置上部のピン治具に取付けら れ，図一6(a) に示すように，梁の両端に下向きの一方 向せん断力を作用させる。十字形試験体では，角形鋼管 柱の下部のオイルジャッキで柱に所定の軸力（柱の降伏 軸力の約 3 割）を導入した後，図一6(b) のように, 梁 の両端に繰返しせん断力を作用させる。加力に当たって は, 梁両端と接合部の 3 点が常に一直線上にあるように 変位制御する。このような加力方法を用いることにより， 図一6(b) の実験で得られた荷重-変形関係を座標変換 して，P- $\Delta$ 効果を含む層せん断力-層間変形角関係に変 換することが出来る5 。

\section{3 測定項目および測定方法}

\section{3 .1 変 位}

単純梁形武験体では, 図一7(a) に示す測定用フレー ムを試験体中央のプレート，またはダイヤフラムに取り

表一4 試験体の断面諸量

\begin{tabular}{|l|c|c|c|c|c|c|c|c|}
\hline \multicolumn{1}{|c|}{ Section } & $\begin{array}{c}\mathrm{A} \\
\left(\mathrm{cm}^{2}\right)\end{array}$ & $\begin{array}{c}\mathrm{A}_{\mathrm{w}} \\
\left(\mathrm{cm}^{2}\right)\end{array}$ & $\begin{array}{c}\mathrm{I} \\
\left(\mathrm{cm}^{4}\right)\end{array}$ & $\begin{array}{c}\mathrm{Z} \\
\left(\mathrm{cm}^{3}\right)\end{array}$ & $\begin{array}{c}\mathrm{Z}_{\mathrm{P}} \\
\left(\mathrm{cm}^{3}\right)\end{array}$ & $\begin{array}{c}\mathrm{N}_{\mathrm{P}} \\
(\mathrm{t})\end{array}$ & $\begin{array}{c}\mathrm{M}_{\mathrm{P}} \\
(\mathrm{t} \cdot \mathrm{cm})\end{array}$ & $\begin{array}{c}\mathrm{M}_{\mathrm{fP}} \\
(\mathrm{t} \cdot \mathrm{cm})\end{array}$ \\
\hline $\mathrm{BH}-350 \times 150 \times 6 \times 9$ & 47.0 & 21.2 & 9620 & 550 & 623 & - & 1920 & 1360 \\
$\mathrm{BH}-250 \times 125 \times 6 \times 9$ & 36.7 & 15.1 & 3890 & 312 & 353 & - & 1090 & 797 \\
$\mathrm{BH}-250 \times 175 \times 6 \times 9$ & 45.3 & 15.1 & 5120 & 411 & 456 & - & 1410 & 1120 \\
\hline$\square-250^{2} \times 12$ & 52.6 & - & 5210 & 417 & 480 & 190 & 1740 & - \\
$\square-250^{2} \times 12$ & 105 & - & 9790 & 783 & 938 & 402 & 3590 & - \\
$\mathrm{D}-250^{2} \times 12$ & 140 & - & 12500 & 999 & 1210 & 487 & 4210 & - \\
\hline
\end{tabular}




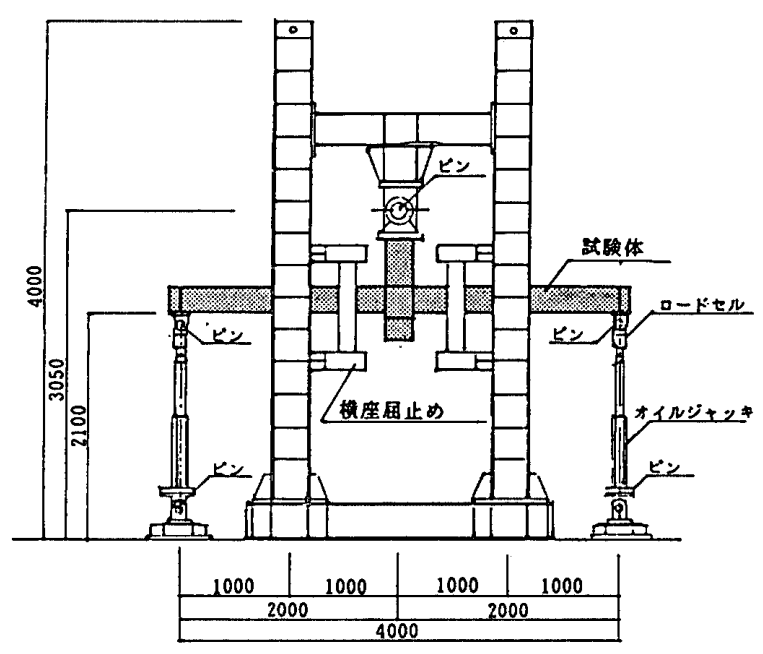

図一5(a) 加力装置 (単純梁形試験体)

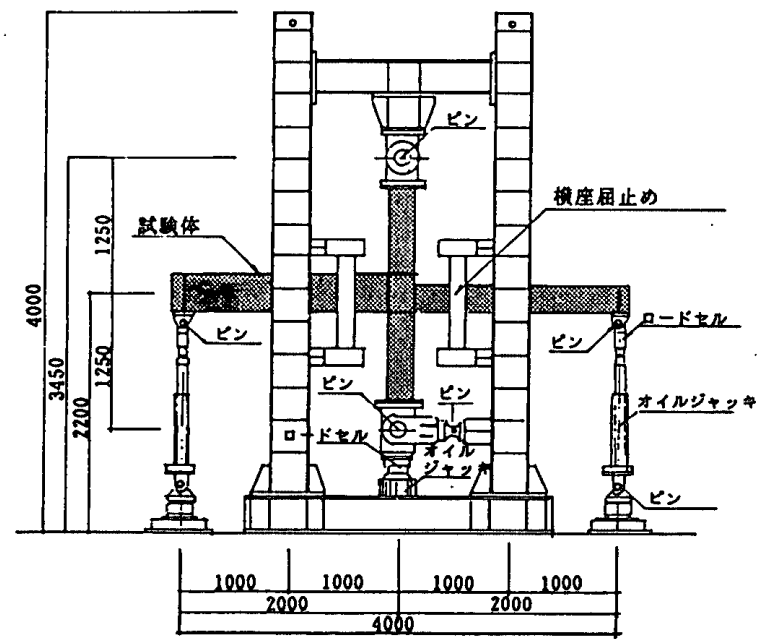

図一5(b) 加力装置（十字形試験体）

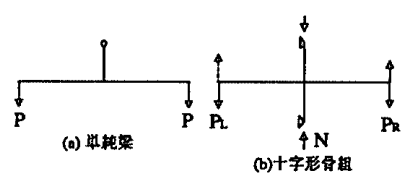

図一6 加力方法
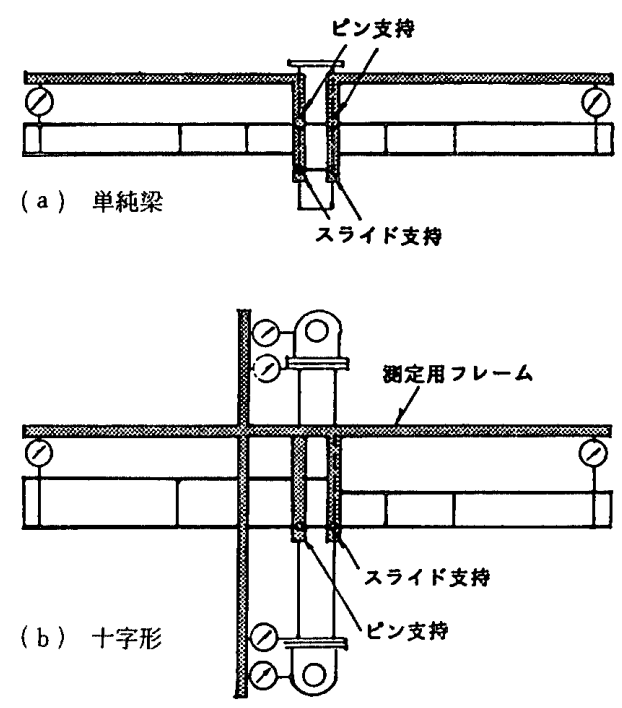

图一7 変位測定フレーム
付け, 梁両端の相対変位を計測する。実験結果としては, 左右 2 本の梁のうち，大きい方の梁の変形を採用する。

十字形試験体の変位の計測点は, 図一7(b) のように 梁両端および柱の上下 2 点ずつであり, さらに, バネル ゾーンの変形も図一8に示す位置で計測する。

\section{3 .2 ひずみ度}

W.S.G.の貼付位置の例を図一9(a)，(b) に示す。単 純梁形試験体では中央の角形鋼管柱には貼付せず，片側 の H 形銅梁だけに貼付している。

\subsection{3 接合部の柱の面外変形}

単純梁形試験体については, 実験終了後, 角形鋼管接 合部のフランジおよびウェブの残留面外変形を計測し， 等高線図を作成する。面外変形の計測は図一10 に示す 画像解析システムによって行った。試験体は変形が起 こっていない部分を基準面としてエマルジョンタイプ白 色ワックスの液槽内に固定設置する。液面の高さを変化

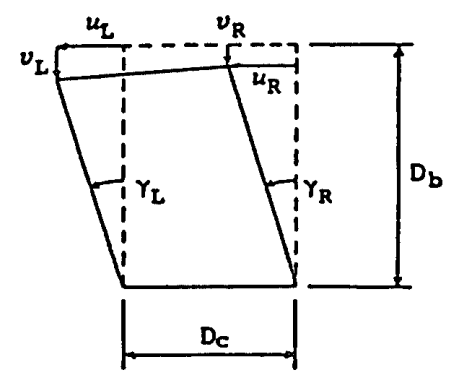

図-8 パネルゾーンの変形

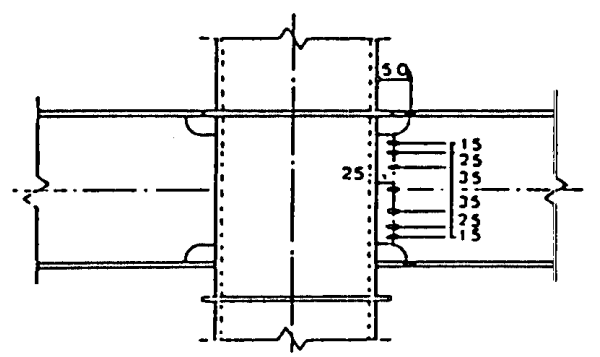

(a) 単純梁形訊験体

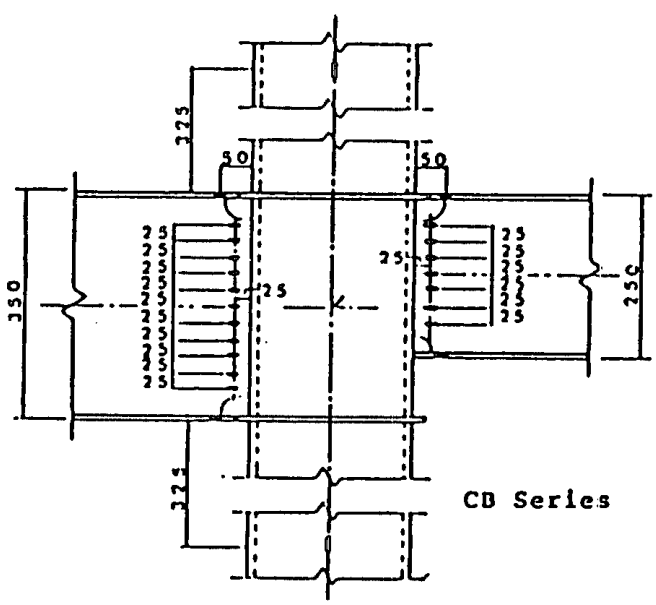

(b) 十字形試験体

図一9ひずみゲージ貼付位置 


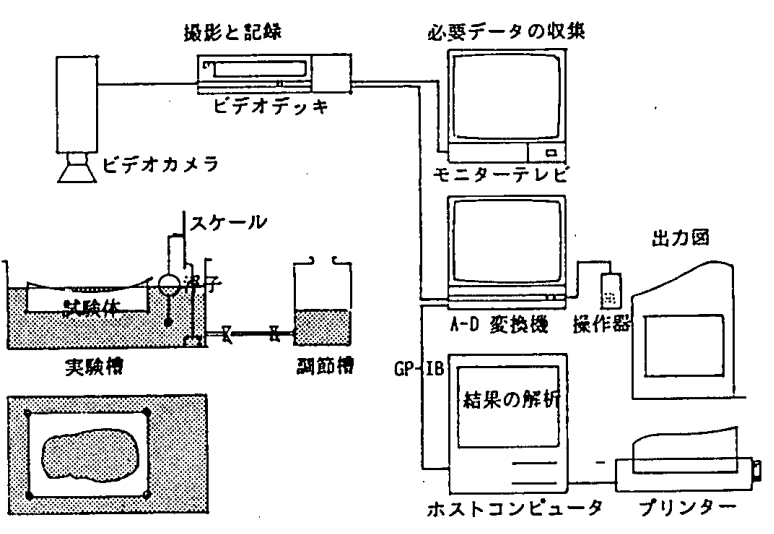

図一10 面外変形の計測システム

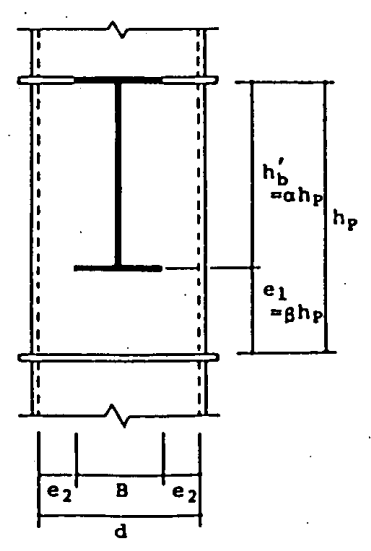

図一13 柱フランジ面

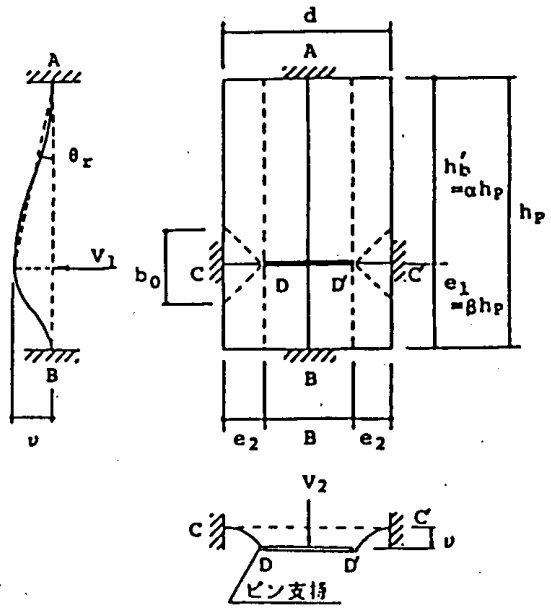

図一14 弾性解析モデル
させ, 各液面高さの状況を試験体の真上からビデオカメ ラで撮影し，ビデオデッキを通してモニターテレビ, $\mathrm{A} / \mathrm{D}$ 変換器に画像を送る。輝度, 色相等の条件を選択 して, A/D 変換器でその条件にあう必要画面を取り込 み,コンピューターを通してハードコピーで等高線図を 出力する。

\section{3. 弾性剛性と塑性耐力}

\section{1 弾性剛性}

\subsubsection{B1 シリーズ試験体の弾性剛性}

梁の上下フランジの位置で通しダイアフラムによって 補剛されているが，梁のウェブは貫通していないから， 図一11 に示す梁のせん断力 $P$ と部材回転角 $\theta$ を関係付 ける剛性 $K$ はせん断変形を考慮して下記の範囲にある。

$$
K_{0}=\frac{1}{\frac{l_{b}^{2}}{3 E I}+\frac{1}{G A_{w}}}>K>K_{1}=\frac{1}{\frac{l_{b}^{2}}{3 E I_{F}}+\frac{1}{G A_{w}}}
$$

ここで，IFはウェブを無視した梁フランジだけの断面 二次モ一メント， $A_{w}$ はウェブの断面積である。

\subsubsection{B2.シリーズ試験体の弾性剛性}

梁の下フランジ位置でダイアフラムによる補強がされ ていない段違い梁では，梁に曲げが作用すると接合部の 柱フランジに面外変形が生じ，これによって梁の端部が 回転して剛性が低下する。したがって，この梁の解析に 当たっては，柱フランジの面外剛性に対応する梁端の回 転バネを導入した図一12 に示すような解析モデルを考 え，回転バネ剛性 $K_{r}$ を次のようにして求める。

図一13に示す柱フランジ面を図一14に示す格子梁に 置換する。この図では，梁 $\mathrm{AB}$ は幅 $B$ の両端固定梁，

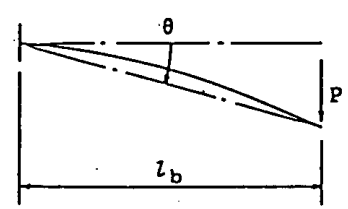

図-11

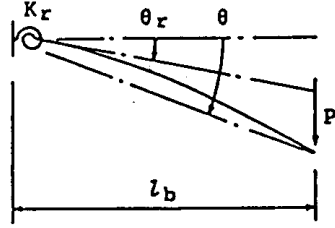

図-12
梁 $C D\left(C^{\prime} D^{\prime}\right)$ は図中に点線で示されているように，梁 の下フランジ端でピン支持の変断面片持ち梁とする。た だし，固定端 $\mathrm{C}\left(\mathrm{C}^{\prime}\right)$ における幅 $b_{0}$ を次のように定義 する。

$$
b_{0}=\operatorname{Min}\left(2 e_{1}, 2 e_{2}\right)
$$

また図一14において，梁の下フランジに相当する $\mathrm{DD}^{\prime}$ の部分は変形しないものとする。格子梁の交点 $\mathrm{DD}^{\prime}$ の変位 $v$ と梁の回転角 $\theta_{r}$ の関係は図一14 に示すと おりであり，梁端モーメント $M$ は上下フランジの偶力 として伝達されるものとすると， $M$ と $\theta_{r}$ を関係付ける 回転剛性 $K_{r}$ は次式のように導功れ。

$$
K_{r}=3 E\left(\alpha h_{\rho}\right)^{2}\left\{\frac{I_{A B}}{\left(\alpha \beta h_{\rho}\right)^{3}}+\frac{4 I_{C D}}{3 e_{2}^{3}}\right\}
$$

ここで， $I_{A B}, I_{C D}$ は，それぞれ梁 $A B$ および固定端に おける梁 $\mathrm{CD}\left(\mathrm{C}^{\prime} \mathrm{D}^{\prime}\right)$ の断面 2 次モーメントである。す なわち，

$$
I_{A B}=\frac{B t_{t}^{3}}{12}, \quad I_{C D}=\frac{b_{0} t_{i}^{3}}{12}
$$

図-12 に示す段違い梁のせん断力 $P$ と部材回転角 $\theta$ を関係付ける弾性剛性 $K_{2}$ は，（3）式の $K_{r}$ を用いて次 式で与えられる。

$$
K_{2}=\frac{1}{\frac{l_{b}^{2}}{3 E I_{F}}+\frac{1}{G A_{w}}+\frac{l_{b}}{K_{r}}}
$$

\section{2 塑性耐力}

\subsubsection{B1 シリーズ試験体の塑性耐力}

図一15に示す接合部を対象にして，梁ウェブから柱 フランジに伝達される塑性モーメントは柱フランジの崩 壊機構を図一16 に示すように想定すると，降伏線理論 ${ }^{12)}$ に基づいて次式占で与えられる。

$$
\begin{aligned}
M_{w c}(X)= & \left.8\left(\frac{D_{f}}{2}-X\right)\left[(\pi-\phi)+\left\{\frac{D_{f}}{2 X}-1\right)^{2}-1\right\}^{1 / 2}\right] M_{0}^{t} \\
& +\frac{D_{\lambda}\left(X-S_{r}\right)}{2 X} N_{0}^{w} \ldots \ldots \ldots \ldots \ldots \ldots \ldots(6)
\end{aligned}
$$

（6）式を $X$ で最小化させる過程は繁雑であり， $M_{w c}$ の厳密解を求めることは困難であるから近似値を用い 


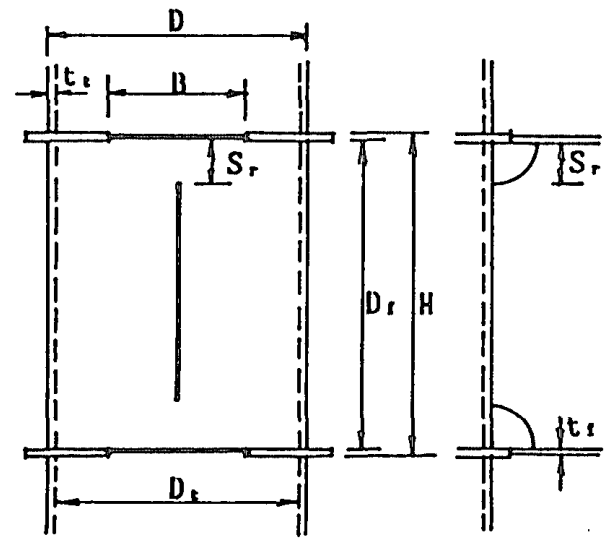

図一15 標準接合部

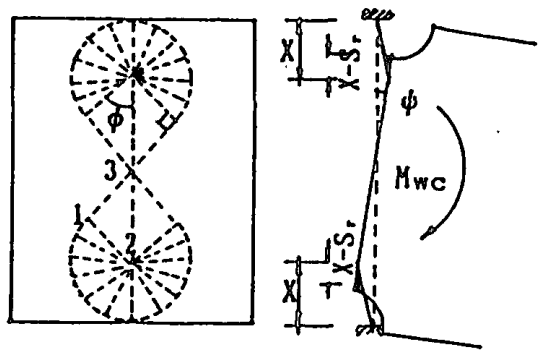

図一16 崩壊機構

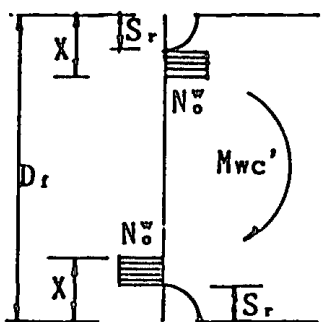

図一17 梁ウェブ応力分布

る。近似值 $M_{w C}^{\prime}$ は，梁ウェブ断面の応力分布を図一-17 に示すようにウェブの断面上下 $X$ の範囲だけに一様な

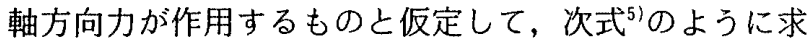
める。

$$
\begin{aligned}
& M_{w C}^{\prime}=\left(X-S_{r}\right)\left(D_{f}-X-S_{r}\right) N_{0}^{w} \\
& X=\left(\frac{4 D_{f} M_{0}^{t}}{N_{0}^{w}}+S_{r}^{2}\right)^{1 / 2}
\end{aligned}
$$

ただし， $M_{0}^{t}$ は鋼管板要素の単位幅当たりの塑性モーメ ントである。梁フランジだけの塑性モーメントを $M_{F P}$ とすると，柱梁接合部で伝達される梁の塑性モーメント の近似值 $M_{c}^{\prime}$ は，（7）式の $M_{w c}^{\prime}$ を用いて次式で与えら れる。

$$
M_{C}^{\prime}=M_{W C}^{\prime}+M_{F P}
$$

ただし， $M_{C}^{\prime}$ は梁断面の全塑性モーメント值 $M_{P}$ を超 えることはできない。

\subsection{2 段違い梁（B2 シリーズ）試験体の塑性耐力}

段違い梁の崩壊機構に関しては，図一18に示すよう に, 二辺の固定端 $\mathrm{PH}, \mathrm{PJ}$ で支持された板の点 0 に集 中荷重が作用する場合の解 ${ }^{12\}}$ を適用する。図一18にお

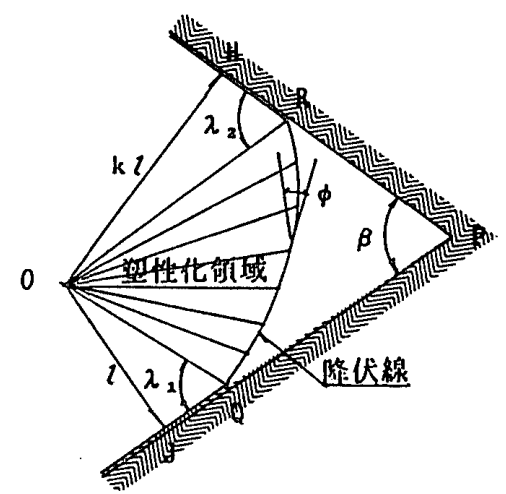

図一18 二辺固定支持板が集中荷重を受ける場合の塑性化領域

いて降伏線の一部である曲線 $Q R$ は等角螺旋であり, 塑性化領域 OQR の応力仕事速度 $W_{i}^{C N}$ は次の上うに導 かれる。

$$
\begin{aligned}
W_{i}^{c N}= & M_{0} u\left\{\cot \lambda_{1}+\cot \lambda_{2}+2\left(\lambda_{1}+\lambda_{2}-\beta\right)\right. \\
& +\frac{2}{\lambda_{1}+\lambda_{2}-\beta}\left(\ln \frac{k \sin \lambda_{1}}{\sin \lambda_{2}}\right)^{2} \ldots \ldots \ldots \ldots
\end{aligned}
$$

ここで, $u$ は荷重点 0 の変位速度であり, 角度パラメー 夕 $\lambda_{1}, \lambda_{2}$ が次の值を取るとき $W_{i}^{C N}$ は最小值を取る。

$$
\lambda_{1}=\frac{1}{2} \pi-\phi, \quad \lambda_{2}=\frac{1}{2} \pi+\phi
$$

$\phi$ は図一18において次式で定義される。

$$
\tan \phi=\frac{1}{\lambda_{1}+\lambda_{2}-\beta} \ln \frac{k \sin \lambda_{1}}{\sin \lambda_{2}}
$$

柱フランジの崩壊機構として図一19に示す機構を仮 定する。この機構の塑性化領域(4)(2)(1)と(4)(3)(6)に対して （10）式を適用すれば，段違い梁の崩壊モーメント $M_{c}$ が次のように得られる。

$$
\begin{aligned}
M_{c}= & 4\left\{\tan \phi_{1}+\left(\frac{\pi}{2}+\operatorname{ant} \frac{B}{2 h_{b}^{\prime}}-\phi_{1}\right) \sec ^{2} \phi_{1}\right. \\
& \left.+\frac{\pi}{2} \sec ^{2} \phi_{2}+\frac{B}{2 e_{1}}\right\} M_{0} h_{b}^{\prime} \cdots \cdots \cdots \cdots \cdots \cdots(1
\end{aligned}
$$

ただし， $M_{C}$ は梁の全塑性モーメント $M_{P}$ を超えるこ とはできない。

\section{4. 実験結果とその考察}

4.1 単純梁形試験体の実験結果

実験結果としては，接合部の両側の梁のうち，大きな

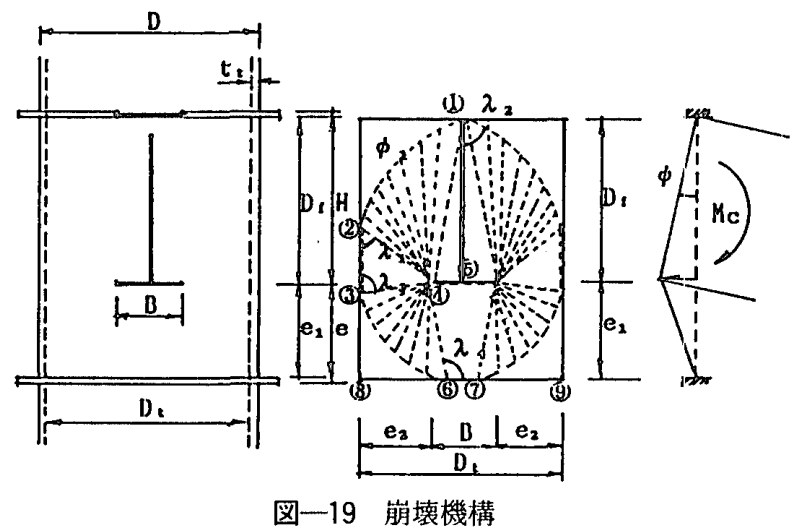




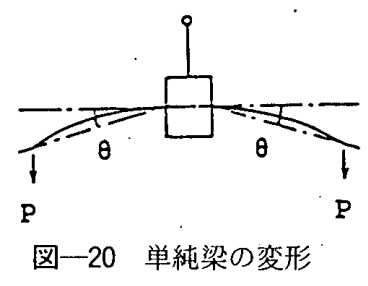

変形が生じた方の結果を採用している。B 1 および B 2 シリーズの各実験結果は, 同じ梁断面で㑉な接合部を持 つ $\mathrm{B} 0$ シリーズの実験結果（以下，これを基準試験值と 略記）と比較して示す。荷重-変形関係としては, 図一 20 に示す梁のせん断力 $P$ と部材回転角 $\theta$ の関係を用い ている。

\subsubsection{B1 シリーズ}

各試験体の $P-\theta$ 関係を図一-21 に示す。図一 22 はそれ らをまとめたものであり，図中の点線は B 0-1 の基準試 験值である。原点を通る 2 本の直線は（1）式の剛性の 上下界 $K_{0}, K_{1}$ を表している。 $P_{P}, P_{F P}$ は，それぞれ梁 の全塑性モーメントおよび梁フランジの全塑性モーメン 卜に対応する荷重レベルであり， $P_{c}$ は $(7)$ 式のモ一 メントに対応する。荷重点 $P_{g P}$ は, 荷重-変形関係の勾 配が初期の $1 / 6$ になった点で, 本論ではこの值を実験值 としている。1/6の勾配を採用した理由は下記のとおり である。

（1）降伏棚が現れる荷重-変形曲線に対しては，ほぼ 降伏棚開始点の荷重レベルに対応する。

（2）降伏棚が認められない荷重一変形曲線の場合には, 剛性が大きく低下する荷重点に対応する。

その他, 図中の記号 FB, WB は，それぞれフランジ
およびウェブに局部座屈が観察された点を表している。

剛な接合部を持っB0-1では明瞭な降伏棚が現れた 、後, ひずみ硬化によって耐力が若干上昇し，ウェブに局 部座屈が生じて耐力が漸減する。一方，B1 シリーズで は降伏棚は認的られず，弾性域から塑性域にかけて徐々 に剛性が低下している。また, よ゙の試験体の最大耐力 $\left(P_{\max }\right)$ も基準試験值に達しているが，管厚 $6 \mathrm{~mm}$ の B11 では, 最大耐力になるのはかなり大きな変形が生じた 後である。B1 シリーズのうち，（7）式から計算され る $M_{C}^{\prime}$ 值が $M_{P}$ 值より小さい試験体はB 1-1だけである。 この試験体に対しては， $P_{c}$ は $P_{g P}$ によく一致している が, B1-2, 3 では $P_{c}\left(P_{P}\right)$ は $P_{g P}$ よりやや大きい。しかし, B1-2，3では，B1-1に比べて小さな変形で $P_{P}$ に達し ており， $P_{\max }$ に達する変形は基準試験值とほぼ同じで ある。

B 0-1 の剛性は理論値 $K_{0}$ にほぼ一致しているが，B1 シリーズでは, 柱の管厚にかかわらず, どの試験体の剛 性も（1）式の下界に非常に近い。

各試験体の荷重が $P_{g P}$ に達したときの接合部近傍の ウェブのひずみ分布を図一 23 に示す。B1 シリーズのひ ずみ度はどれも基準試験值よりかなり小さい。

図一24 は, B1-1 の実験終了後の接合部柱フランジの 面外変形を $1 \mathrm{~mm}$ ピッチの等高線で示したもので, 図一 16 の崩壊機構に類似している。なお, 他の 2 体の試験 体ではほとんど変形が検出されなかったので図を省略す る。

\subsubsection{B2 シリーズ}

各試験体の $P-\theta$ 関係を図一 25 に示す。図中の記号は
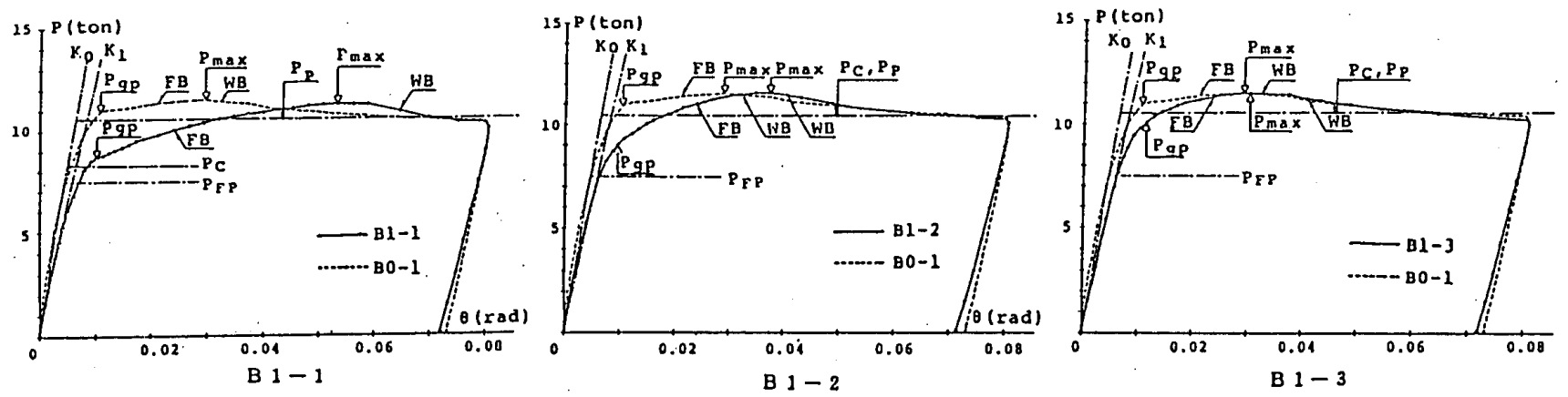

図一21 $P-\theta$ 関係（B1 シリーズ）

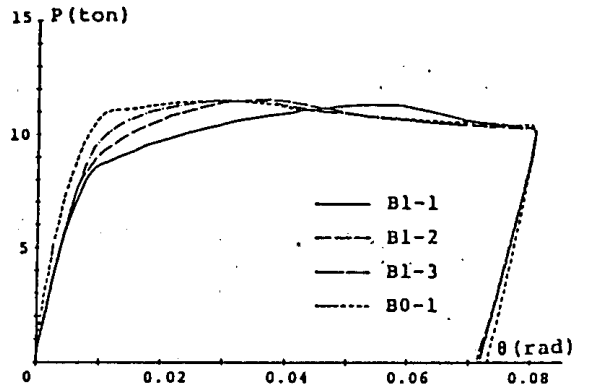

図-22 $P-\theta$ 関係

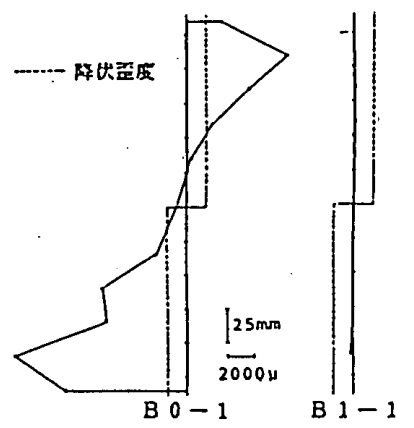

図一23 ウェブのひずみ度分布 $\left(P=P_{g P}\right)$

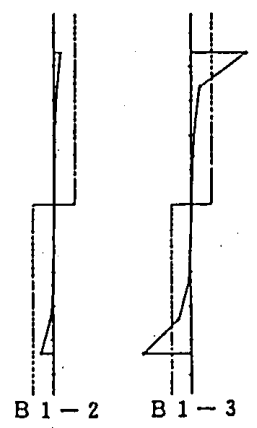

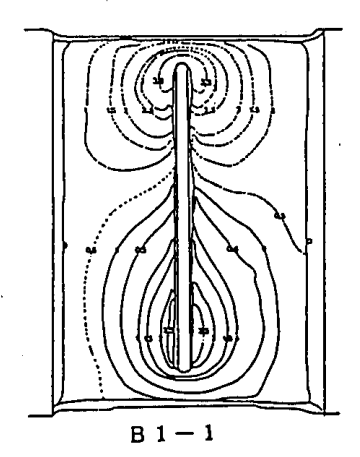

図一24 面外変形 


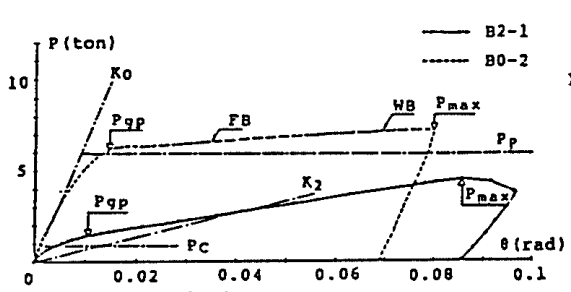

(1) B 2-1

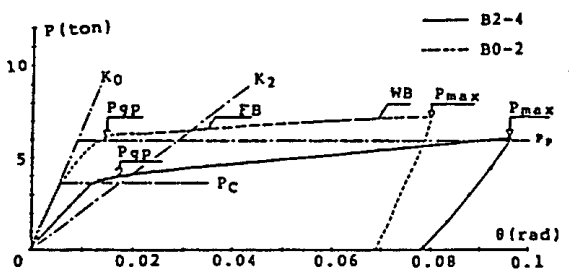

(4) $\mathrm{B} 2-4$

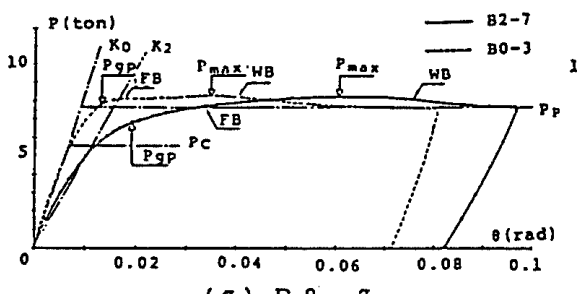

(7) B 2-7

図一25 P- $\theta$ 関係 (B2 シリーズ)

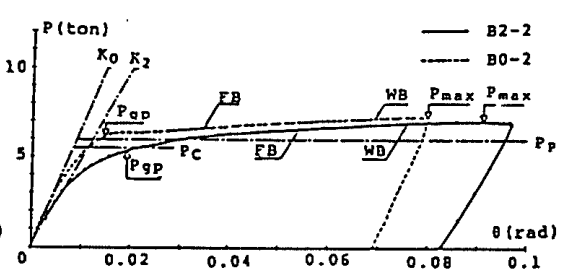

(2) B 2-2

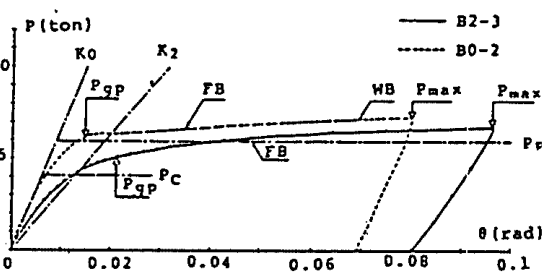

(3) B 2-3

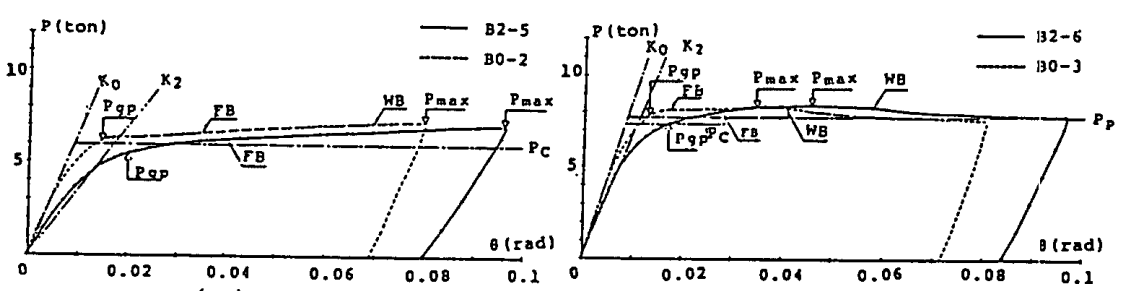

(6) В $а-6$

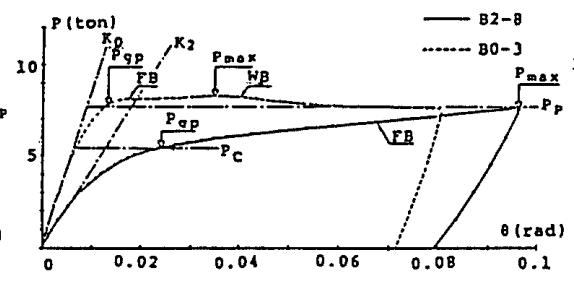

(8) B $2-8$

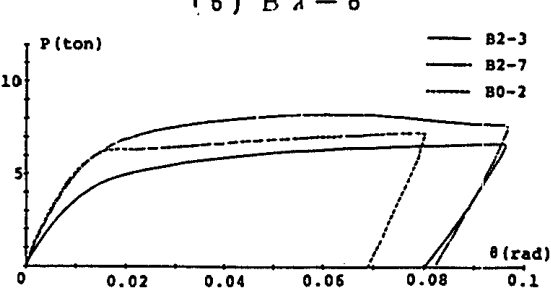

図一26 $\quad P-\theta$ 関係

前項と同じであるが, 判性については $K_{1}$ の代わりに (5) 式から得られる $K_{2}$ を示している。酎力, 剛性と もに，どの試験体も基準試験值に比べて明らかに低下し ており，当然のことながら，柱の管厚が薄くなるほど， また段差が大きくなるほどこの傾向は顕著である。解析 值と実験值とを比較すると, 図一14の格子梁モデルか ら得られる剛性 $K_{2}$ は, 全体に実験值をやや過小評価す る傾向にある。

また, 図一19 の崩壊機構から導かれる耐カレベル $P_{c}$ と $P_{g P}$ とは比較的よく一致していると言えよう。

図一26は，段差 $e$ が $50 \mathrm{~mm}$ の場合の 2 種類の梁断面 に対する実験結果を比較したものであり，点線はB0-2 の基準試験值である。B2-7 の耐力はB0-2 のものを超 えており,このことから, 段違い梁の補強方法として内
ダイアフラムやハンチなどを用いなくても, 梁の端部で フランジ幅を広げるという簡便な補強で梁の全塑性值に 到達できる可能性があると言える。表一5 は単純梁形試、 験体の弾性剛性, 塑性耐力の解析値と奏験值をまとめた ものである。

接合部の柱の永久面外変形の一例を図一 27 に示す。 B2 シリーズでは, クリップリングの有無を調べる目的 でウェブの面外変形も計测したが，柱の管厚 $6 \mathrm{~mm}$ のも の以外ではほとんど検出されなかった。図一 27 に示さ れているフランジ面の変形状態は図一19 の崩填機構と よく似ている。

\section{2 十字形 ( $\mathrm{CB}$ シリーズ) 試験体}

\subsection{1 繰返し加力実験結果}

図一 28 に示すように, 十字形試験体はラーメン架棈
表一5 単純梁試験体の弾性剛性と塑性耐力

\begin{tabular}{|c|c|c|c|c|c|c|c|c|}
\hline \multirow{3}{*}{ Specimen } & \multicolumn{5}{|c|}{ 弹性㓮性 } & \multicolumn{3}{|c|}{ 塑性耐力 } \\
\hline & \multicolumn{2}{|c|}{ 解析值 } & \multirow{2}{*}{$\begin{array}{c}\text { 湊馱值 } \\
\mathrm{Ke} \\
(\mathrm{t} / \mathrm{rad})\end{array}$} & \multirow[b]{2}{*}{$\frac{K e}{K_{1}\left(K_{2}\right)}$} & \multirow[b]{2}{*}{$\frac{\mathrm{K} e}{\mathrm{~K}_{0}}$} & \multirow{2}{*}{$\begin{array}{c}\text { 解析值 } \\
\text { P c } \\
\text { (ton) }\end{array}$} & \multirow{2}{*}{$\begin{array}{l}\text { 実䀫值 } \\
\mathrm{P} \text { gP } \\
\text { (ton) }\end{array}$} & \multirow[b]{2}{*}{$\frac{P_{g P}}{P_{c}}$} \\
\hline & $\begin{array}{c}\mathrm{K}_{\mathrm{o}} \\
(\mathrm{t} / \mathrm{rad})\end{array}$ & $\begin{array}{l}\mathrm{K}_{1}\left(\mathrm{~K}_{2}\right) \\
(\mathrm{t} / \mathrm{rad})\end{array}$ & & & & & & \\
\hline B0-1 & 1570 & & 1620 & & 1.03 & 10.5 & 11.0 & 1.04 \\
\hline B0-2 & 655 & & 586 & & 0.89 & 5.85 & 6.20 & 1.06 \\
\hline $\mathrm{B} 0-3$ & 857 & & 843 & & 0.98 & 7.61 & 7.86 & 1.03 \\
\hline B1-1 & 1540 & 1220 & 1190 & 0.97 & 0.77 & 8.21 & 8.51 & 1.04 \\
\hline $\mathrm{B} 1-2$ & 1570 & 1240 & 1250 & 1.01 & 0.80 & 10.6 & 9.31 & 0.88 \\
\hline B 1-3 & 1560 & 1240 & 1260 & 1.02 & 0.81 & 10.5 & 10.1 & 0.96 \\
\hline B2-1 & 664 & 65 & 268 & 4.12 & 0.41 & 0.85 & 1.43 & 1.68 \\
\hline B 2-2 & 653 & 481 & 524 & 1.09 & 0.80 & 5.51 & 5.33 & 0.98 \\
\hline B $2-3$ & 666 & 317 & 400 & 1.26 & 0.61 & 4.04 & 5.07 & 1.25 \\
\hline B2-4 & 356 & 200 & 291 & 1.46 & 0.44 & 3.65 & 3.99 & 1.09 \\
\hline B2-5 & 661 & 343 & 401 & 1.17 & 0.61 & 5.99 & 5.49 & 0.92 \\
\hline B 2-6 & 853 & 676 & 694 & 1.03 & 0.81 & 7.33 & 7.37 & 1.01 \\
\hline B 2-7 & 851 & 499 & 551 & 1.10 & 0.64 & 5.59 & 6.86 & 1.23 \\
\hline B 2-8 & 850 & 422 & 384 & 0.91 & 0.45 & 5.45 & 5.46 & 1.00 \\
\hline
\end{tabular}

ただし、( $\left(K_{2}\right)$ はB2シリースの暍合

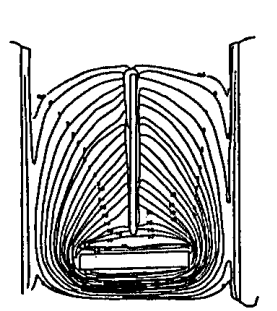

(a) フランジ面

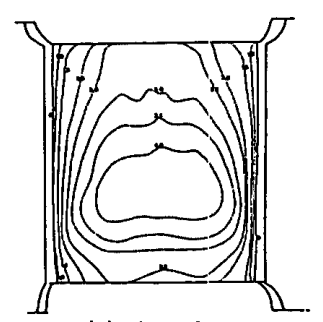

(b) ウェフ面

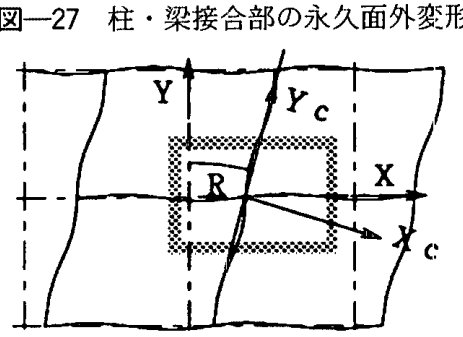

図一28 試験体位置 
の一部を切り出したものである。梁の部材角が常に零を 保つよう架構の変形状況を想定し, 十字形試験体の加力 に当たっては，図一 30 に示すように梁両端および接合 部の 3 点が常に一直線上にあるように変位を制御してい る。

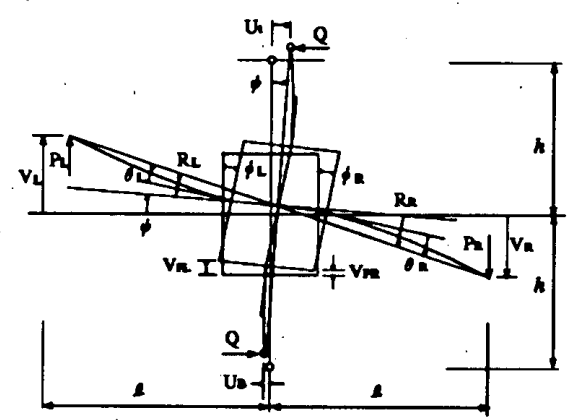

図一29十字形試験体の測定変位

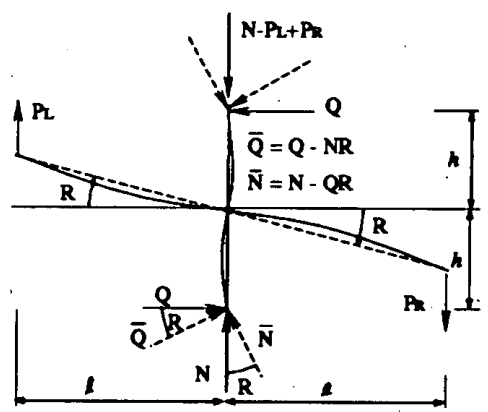

図-30 $\bar{N}, \bar{Q}$
十字形試験体の実験結果を図一 31 3 33 に示す。CB-1 以外の試験体に注, すべて柱に 133 ton（軸力比：0.33） の軸力が作用している。

図一31( 1$) \sim(5)$ は各試験体の $Q-R$ 関係である。 ただし，CB-4 試験体はCB-3 と同じで，加力時の変位 振幅が異なるだけである。図中の点線は解析結果を表す。 原点を通る直線はパネルン゙ーンのせん断変形 ${ }^{13)}$ を考虑 し，断差のない梁に対しては（1）式で示される $K_{1} を$ 用い，段違い梁については接合部柱フランジの面外変形 を考虑した（5）式の剛性 $K_{2}$ を適用したものである。 一点鎖線は接合部の柱フランジを剛としてその面外変形 を無視した場合の剛性を表している。水平あるいは右下 がりの点線は崩壊機構線であり， $Q_{P}$ および $Q_{C}$ は，そ れぞれ左右の梁の全塑性值および接合部柱フランジ面の 崩壊荷重に対応する荷重レベルである。さらに, 図一31 中の各記号は下記の現象が観察された点を示すもので, 最初の英字として LとRで左側および右側の梁を区別し ている。

FB WB：フランジまたはウェブに局部座屈発生

FC : スカラップ端部の梁に亀裂発生

$\mathrm{FT}$ : 梁フラ:シジ破断

実験結果と解析結果の弹性剛性と芣性耐力を表一6に まとめて示す。

図一 32 は, 接合部パネルゾーンの平均せん断応力度 ( $\tau)$ と測定値の平均せん断変形 $(\gamma)$ との関係を表すもの で，ては（14）式で算出している。

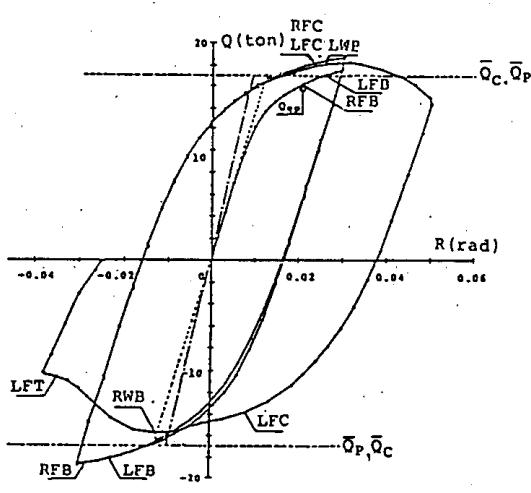

(1) $\mathrm{CB}-1$

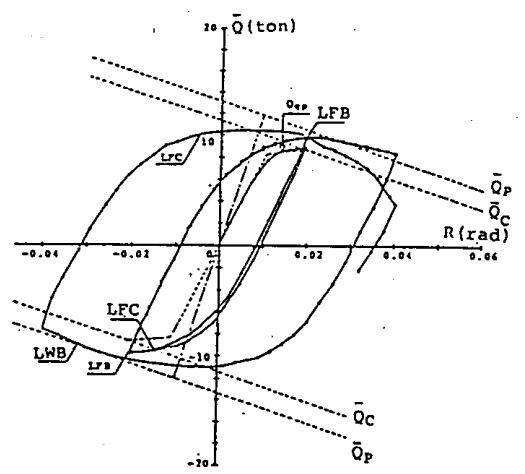

(4) $\mathrm{CB}-4$

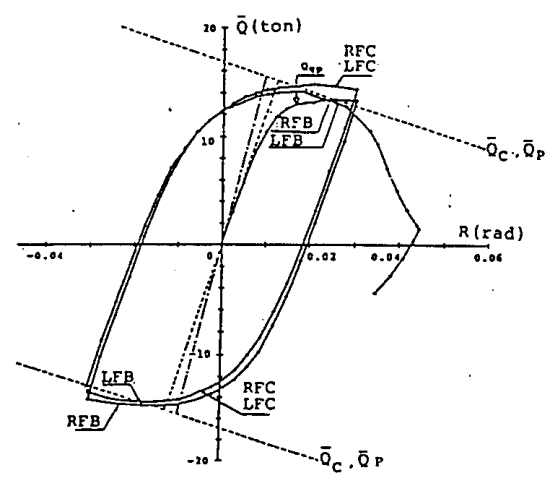

(2) $\cdot \mathrm{CB}-2$

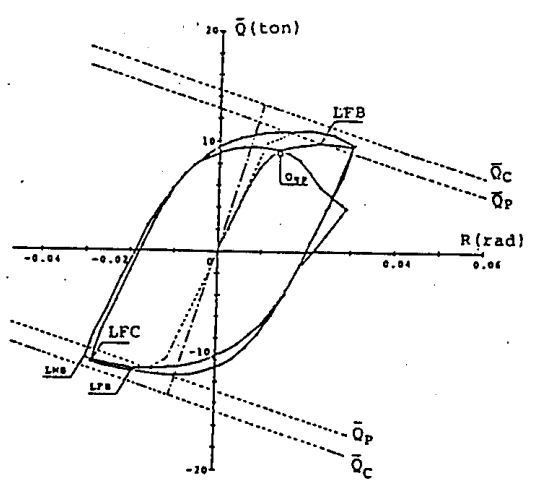

(5) $\mathrm{CB}-5$

図一31 Q- $R$ 関係

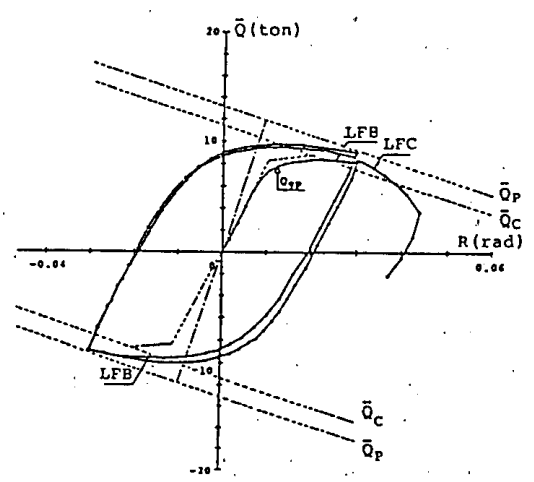

(3) $\mathrm{CB}-3$ 


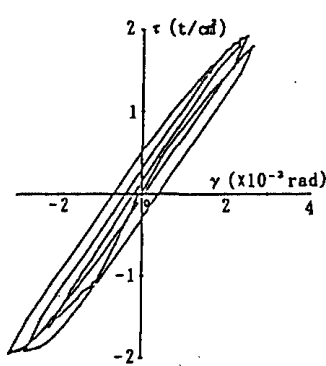

(1) $\mathrm{CB}-1$

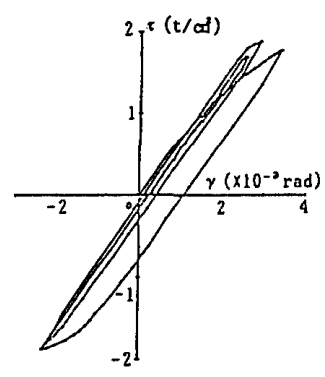

(2) $C B-2$

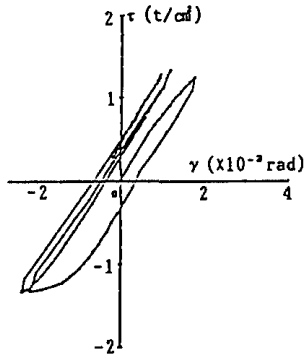

(3) $\mathrm{CB}-3$

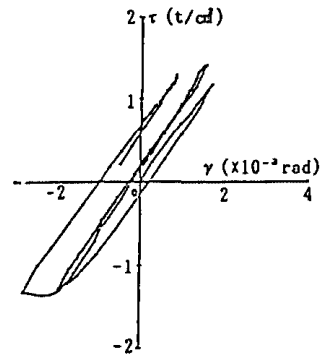

(4) $\mathrm{CB}-4$

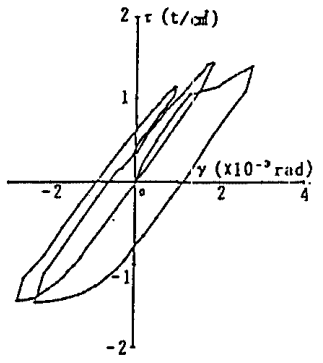

(5) $C B-5$

図一32 パネルゾーンの $\tau-\gamma$ 関係
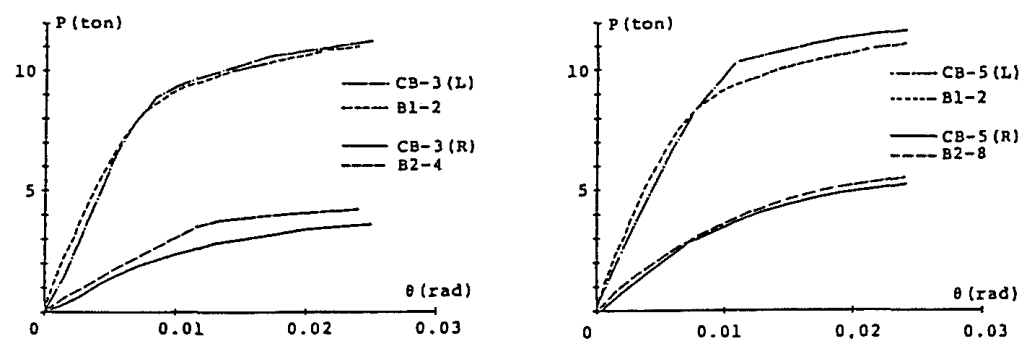

図一33 梁の $P-\theta$ 関係

表一 6 十字形試験体の弾性剛性と塑性耐力

\begin{tabular}{|c|c|c|c|c|c|c|c|c|}
\hline \multirow{3}{*}{ Specimen } & \multicolumn{5}{|c|}{ 弾性㓮性 } & \multicolumn{3}{|c|}{ 望性咉力 } \\
\hline & \multicolumn{2}{|c|}{ 解析値 } & \multirow{2}{*}{$\begin{array}{c}\text { 実験值 } \\
\mathrm{Ke} \\
(\mathrm{t} / \mathrm{rad})\end{array}$} & \multirow{2}{*}{$\frac{\mathbf{K e}}{\mathbf{K} \mathbf{1}}$} & \multirow{2}{*}{$\frac{\mathbf{K e}}{\mathbf{K o}}$} & \multirow{2}{*}{$\begin{array}{c}\text { 解析值 } \\
\text { Qc } \\
\text { (ton) }\end{array}$} & \multirow{2}{*}{\begin{tabular}{|c|} 
荑験值 \\
Qgp \\
(ton) \\
\end{tabular}} & \multirow{2}{*}{$\frac{\mathrm{Qgp}}{\mathrm{Qc}}$} \\
\hline & $\begin{array}{c}\text { Ko } \\
\text { (U/rad) }\end{array}$ & $\begin{array}{c}\mathbf{K} \mathbf{1} \\
(\mathrm{W} / \mathrm{rad})\end{array}$ & & & & & & \\
\hline CB-1 & 1760 & 1350 & 1290 & 0.96 & 0.73 & 16.9 & 16.2 & 0.96 \\
\hline CB-2 & 1620 & 1210 & 1120 & 0.83 & 0.69 & 15.2 & 12.9 & 0.85 \\
\hline CB-3 & 1230 & 761 & 792 & 1.00 & 0.64 & 8.68 & 8.57 & 0.99 \\
\hline $\mathrm{CB} 4$ & 1230 & 789 & 827 & 1.05 & 0.67 & 8.66 & 7.73 & 0.89 \\
\hline CB-5 & 1300 & 894 & 830 & 0.93 & 0.64 & 10.8 & 9.29 & 0.86 \\
\hline
\end{tabular}

Ko：柱フランシの面外変形を考慮せず $\mathrm{K} 1$ ：柱フランシの面外变形を考䖒

$$
\tau=\frac{M_{L}+M_{R}-Q \cdot j_{b}}{V_{P}}
$$

ここで, $M_{L}, M_{R}$ は左右の梁端モ一メント， $V_{P}$ はパネ ルゾーンの体積である。ただし， $V_{P}$ は左右の梁のうち 大きい梁のフランジ中心間距離 $j_{b}$ と柱の管壁厚 $t_{t}$ の積 である。

図一33 は，段違い梁を持つ十字形試験体 (CB-3，5) の左右の梁のせん断力と部材回転角（図一 $29, \theta_{L}, \theta_{R}$ ) の処女載荷時の関係であり, 同図中には同じ断面の単純 梁試験結果も示している。

\section{2 .2 実験結果の考察}

図一 31 , 表一6に示すように, 弾性剛性に関しては夷 験値は解析値と良く一致している。これに対して, どの 試験体も崩壊機構線の荷重レベルは超えているが，単純 梁試験と同様，線形性からの離脱は早期に生じている。 この結果, 処女載荷における塑性耐力については, 解析 値は実験値を上回っている。

繰返し加力に対しては, 図一 34 に示すように, どの 試験体の梁にもスカラップ端部の引張側フランジ中央に 亀裂が発生し, それが両側に進展して破断に至っている。 図中に点線で示しているように，破断箇所のフランジに は絞りが生じていた。ただし，フランジに粕裂が生じた
のは, CB-4, 5 試験体では段差の無いせいが大きい方 のH形鋼梁のみである。無補強段違い梁では，接合部柱 フランジの面外変形によって梁の変形が吸収され，亀裂 は生じていない。図一35は接合部付近の溶接詳細を示 すものであるが，この図における梁フランジの $\mathrm{AB}$ 部 分が他の部分に比べて構造的な欠陥もしくは弱点になっ ており，この部分にひずみが集中して破断に至ったこと は明らかである。

図一32の $\tau-\gamma$ 関係については, CB-1, 2 どちらも若 干降伏域に入っているが, 軸力比が 0.33 程度ではその 影響は認められない。一方, 無補強段違い潹を持つ $\mathrm{CB}-3,4,5$ の場合, かなり低いレベルで明らかに塑性 化が生じている。

図一33 は十字形試験体と単純梁形試験体の各梁のせ ん断力と部材回転角を比較したものであるが, 右側の段 違い梁については，十字形試験体の梁の耐力は単純梁の それと同程度かそれよりやや低くなっている。

\section{5. 結 論}

本論では，角形鋼管柱と左右の梁せいが異なる無補強 段違い梁の接合部における応力伝達機構に関する解析的 研究を行い, 梁の弾性剛性, 終局曲げ耐力の算定式を導 
いた。また，単純梁形試験体について単調載荷実験，十 字片試験体について正負交番繰返し加力実験を行い，梁 の弾性剛性, 終局曲げ耐力の算定式を実験結果と比較し て, その妥当性について考察した。さらに，無補強段違 い梁の実験結果は剛接合部と標準接合部を持つ同じ形状 の梁に対する曲げ試験結果と比較して検討・考察した。 得られた結果を要約すれば，下記のとおりである。 （1）梁の下フランジとダイアフラムに段差がある段違 い梁の弹性剛性および塑性耐力は，当然のことながら段 差が大きくなるほど，また柱の管厚が薄くなるほど低下 する。しかし，段差が小さい場合や柱の管厚が大きい場 合には, 剛性・耐力の低下量はわずかであり, 最大耐力 は基準試験值に達している。

（2）段違い梁の弾性剛性については，柱フランジ面を 格子梁に置換したモデルで面外変形の効果を考慮するこ とにより評価できるが，計算值は実験値をやや過小評価 する傾向がある。一方, 塑性耐力については, 降伏線理 論を用いた柱フランジ面の面外変形機構に基づく計算値 によっておおむね予測できる。

（3）十字形試験体の弾性剛性については, 単純梁形試 験体に用いた方法を適用し,さらに, パネルゾーンのせ ん断変形を考慮することによって, 計算値は実験值に良 く一致する。塑性耐力については, 単純梁の場合と同様, 計算値は実験値をやや過大に評価する。

一方の梁が段違い梁の場合には，パネルゾーンのせん 断耐力がかなり低下する。したがって，水平力を負担す るような段違い梁が接合される部分では何らかの補強策 を講ずる必要がある。なお，この試験体では数回の繰返 し加力の後, スカラップによる断面欠損部のフランジに 絞りが生じて破断した。

\section{謝 辞}

本実験研究について, 大阪大学工学部建築学科五十嵐 定義教授より貴重な御助言を頂いた。また，阪急電鉄 (株) 杉本正三氏 (当時, 大阪大学大学院生), 菊池鉄工 (株) 西植文計氏（当時, 近畿大学研究生）の多大な助 力を得た。ここに記して謝意を表します。

\section{参考文献}

1）日本建築学会：鋼管構造設計施工指針・同解説，1980 年 5 月

2）福田浩司，金谷 弘，田淵基嗣：通しダイアフラム補剛
による角形鋼管柱・H形はり接合部の弾塑性性状 その 3, 鋼管幅厚比の影響, 日本建築学会大会学術講演梗概集, pp. 973-974, 昭和 63 年 10 月

3）福田浩司, 金谷 弘, 田淵基嗣, 佐柳光昭 : 角形鋼管柱 · はり接合部の力学性状に与える接合部詳細の影響 その 4, はりフランジの 2 次曲げの影響, 日本建築学会大会学 術講演梗概集, pp. 1217-1218,1989 年 10月

4）田淵基嗣, 坂本真一, 金谷 弘, 藤原勝義, 上場輝康 : 角形鋼管柱に接合される $\mathrm{H}$ 形鋼はり端部の曲げ耐力の評 価, 日本建築学会構造系論文報告集, 第 389 号, pp. $122-131$, 昭和 63 年 7 月

5）立山英二, 井上一朗, 杉本正三, 松村弘道：通しダイア フラム形式で角形鋼管柱に接合されるH形断面はりの耐 力之変形性能に関する研究一日本建築学会構造系論文報 告集, 第 389 号, pp. 109-121, 昭和 63 年 7 月

6）中尾雅躬，小佐野宏：左右のはりせいが巽なる H 形鋼強 軸交差形柱はり接合部に関する研究，日本建築学会大会 学術講演梗概集, pp. 917-918, 昭和 60 年 10 月

7）中尾雅躬，小佐野宏：左右のはりせいが異なるH形鋼強 軸交差形柱はり接合部に関する研究 その 2 : 梁せい比 が復元力特性に与える影響について, 日本建築学会大会 学術講演梗概集, pp. 1195-1196，1989 年 10 月

8）平野道勝, 吉田幸弘, 西上誠, 今井兼久, 渡辺富雄 : 段差を有する柱はりパネルゾーンの力学的研究に関する 研究, 社団法人鉄骨建設業協会鉄骨, Vol. 10, pp. 29-37, 1988.6

9）今井兼久, 平野道勝, 吉田幸弘, 西上誠, 渡辺富雄 : 段差を有する柱はり接合部の力学的研究に関する研究, その $1 \sim そ の 3$, 日本建築学会大会学術講演梗概集, pp. 1203-1208，1989 年 10 月

10）万木 宏, 梅沢宣雄, 上井康生, 福知保長 : 段差を有す る柱・はり仕口部の耐力実験 その 1, その 2, 日本建築 学会大会学術講演梗概集, pp. 1199-1202, 1989 年 10 月

11）立山英二, 五十嵐定義, 井上一朗, 張 - 雨田, 杉本正三, 松村弘道：通しダイアフラム形式の角形銅管柱・H形鋼 はり接合部におけるはりの応力伝達機構に関する研究 (そ の 1 その 3), 日本建築学会大会学術講演梗概集, pp. 929-934, 昭和 60 年 10 月

12) E. H. Mansfield : Studies in Collapse Analysis of RigidPlate with Square Yield Diagram, Proc. of the Royal Society London, 241, Series A, pp.311-338, Aug., 1957

13）日置興一郎, 中本嘉彦：接合部のせん断変形を考慮した たわみ角法, 日本建築学会論文報告集, 第 101 号, pp. $39-44,1964$ 年 8 月

(1990 年 2 月 10 日原稿受理, 1990 年 8 月 28 日採用決定) 